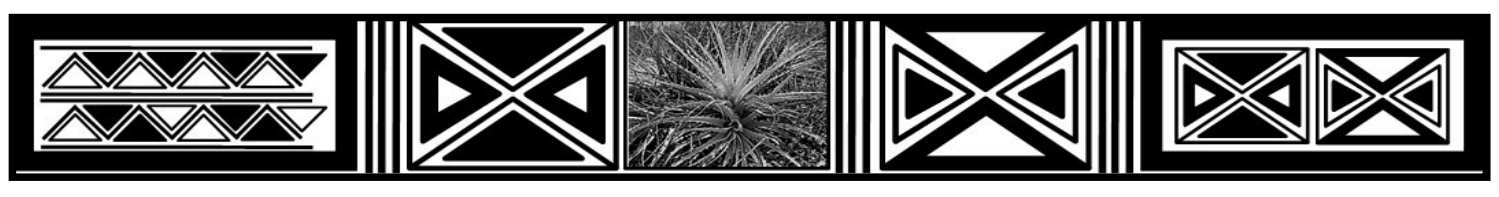

\title{
REVISTA MACAMBIRA
}

LABORATÓRIO DE POLÍTICAS PÚBLICAS, RURALIDADES E DESENVOLVIMENTO TERRITORIAL

Volume 2. Número 1. 2018.

\section{RELAÇÕES ÉTNICO-RACIAIS NA DOCÊNCIA EM CLASSES MULTISSERIADAS}

\section{Antonio José de Souza}

Mestre em Educação e Diversidade (UNEB). Especialista em Desenvolvimento Sustentável no Semiárido com Ênfase em Recursos Hídricos (IFbaiano/Senhor do Bonfim). Licenciado em História pela Faculdade de Ciências da Bahia. Bacharel em Teologia pela Faculdade Católica de Fortaleza. Integrante do Grupo de Pesquisa DIVERSO - Docência, Narrativas e Diversidades - do Grupo de Pesquisa DIFEBA - Diversidade, Formação, Educação Básica e Discursos - e da Associação Brasileira de Pesquisadores/as Negros/as - ABPN.

E-mail: tonnysouza@gmail.com

\section{Jane Adriana Vasconcelos P. Rios}

Pós- Doutora em Educação. Professora Titular da Universidade do Estado da Bahia, no Departamento de Educação - Campus I. Professora do Programa de Pós-Graduação em Educação e Contemporaneidade.

E-mail: jhanrios1@yahoo.com.br

\section{ARTIGO}

Recebido: 12 de dezembro de 2017

Aceito: 10 de março de 2018

RESUMO: Este estudo buscou identificar como a identidade e a cultura afro-brasileira emergiam nas histórias de vida, formação-profissão dos docentes da roça de classes multisseriadas do município de Itiúba, interior da Bahia, através de uma pesquisa-formação atravessada pela fenomenologia e hermenêutica que através da abordagem (auto)biográfica revelou a hesitação dos docentes em cumprir a Lei 10.639/2003 por terem sido imersos em um contexto de negação da identidade e cultura negra. Foi realizado o Ateliê (auto)biográfico oportunizando experiências formativas a partir da relação entre educação e questões étnico-raciais. Percebemos a necessidade de refletir sobre o lugar do negro nas histórias de vida desses professores para que fosse possível pensar em uma proposta construída com eles a partir de suas próprias trajetórias de vida/formação/negação.

Palavras-chave: Identidades. Lei no 10.639/2003. Formação docente. Pesquisa (auto)biográfica.

ABSTRACT: This study sought to identify as the identity and the Afro-Brazilian culture emerged in the life stories, vocational training of the countryside's teachers in the Multiseriate classes of the municipal of Itiúba, in the countryside of Bahia, through a research - training traversed by 
phenomenology and hermeneutics that through the (auto)biographical approach revealed teachers' hesitation to comply with the law 10,639 / 2003 for to them having been immersed in a context of denial of identity and black culture. The (auto) biographical atelier was held, providing training experiences based on the relationship between education and ethnic-racial issues. We notice the necessity to reflect on the black's place in the life stories of these teachers so that it was possible to think of a proposal built with them from their own life trajectories / training / denial.

Keywords: Identities. Law 10.639/2003. Teacher training. Research (auto) biographical.

\section{INTRODUÇÃO}

Este estudo caminhou pelas veredas das histórias de vida, formação e profissão docente, na verdade os/as docentes envolvidos/as nessa tessitura foram como tecelões/ãs, a própria 'Moça Tecelã' contada por Marina Colasanti (2000) que com toda delicadeza literária, fala-nos das "lãs mais vivas, quentes lãs iam tecendo hora a hora, em longo tapete que nunca acabava". Desta maneira, trata-se de um trabalho tecido por exímios/as tecelões/ãs que lançando mão das "linhas" das reminiscências pessoais, teceram enquanto refletiam sobre a identidade e a cultura afro-brasileira, desfazendo, assim, o tear da 'velha tapeçaria' que agasalhou, por muito tempo, as manobras que tinham o objetivo de tornar ínfimas as heranças históricas e culturais, tanto quanto depreciar a identidade do povo negro.

Povo negro que desembarcado nessas terras fez do Brasil, segundo censo do Instituto Brasileiro de Geografia e Estatística (IBGE) de 2010, o país com o maior número de negros/as fora do continente africano, procedente de uma ruptura populacional imposta, isto é, somos um agrupamento humano, organizado em sociedade mantido e sustentado pelo continente negro. Ainda assim, as culturas africanas permanecem desconhecidas para grande parte dos brasileiros e quando descortinadas ganham uma marca estigmatizada e subjugada, colocando, negros/as, numa posição desigual diante aos demais grupos étnico-raciais partícipes da identidade e cultura brasileira.

Lamentavelmente, ainda predomina a insistência em manter $\mathrm{o} / \mathrm{a}$ negro/a despojado/a de sua humanidade, assim como foi feito quando o Atlântico serviu de travessia para as importações contrabandeadas de africanos que forçosamente foram obrigados a participarem da corrente migratória, intitulada pela história por 'diáspora', que vem a ser o deslocamento descontínuo, responsável pela instabilidade populacional e o rompimento com a população-mãe-África. Assim, aportaram no Brasil, na condição de escravizados, a fim de trabalharem no desenvolvimento da colônia, imersos num processo de intensa e verdadeira dominação. 
Do âmago dessas reflexões, brota a convicção de que as mudanças oriundas da contemporaneidade têm, inevitavelmente, respingado nas velhas e retorcidas estruturas escolares, advertindo-a sobre o surgimento da diversidade cultural como fundamento estruturante da educação nacional, rompendo, conforme Macedo (2007, p. 26), com a despropositada "história de alijamentos e de silenciamentos de vozes advindas de segmentos socioculturais não hegemônicos [...]”.

Neste ponto, evidencia-se a desigualdade racial, perpassando o arcabouço educacional brasileiro, gerando disparidades que, no contexto das escolas da roça ${ }^{1}$, são ainda mais patentes, tendo em vista os resíduos patriarcais e escravocratas de uma cultura dominante como as existentes no sertão baiano ${ }^{2}$. Nestas escolas foi, também, destinada uma lastimável herança de precariedades no tocante a estrutura física, formação inicial e continuada dos/as docentes, propostas pedagógicas e materiais didáticos descontextualizados, entre outros. Portanto, de que maneira a prática do/a professor/a da roça ou da sede do município, poderia auxiliar na superação dos mecanismos que subjugam, violentam e negam os direitos garantidos pelas políticas públicas educacionais e curriculares? Coadunando com essa perspectiva, este trabalho nasceu de uma pesquisa-formação que procurou i) Identificar como a identidade e a cultura afro-brasileira emergem nas histórias de vida, formação-profissão dos docentes da roça; ii) Compreender os sentidos construídos pelos docentes a partir da relação entre educação e questões étnico-raciais.

Desse modo, a realização da pesquisa fundamentou-se na abordagem (auto)biográfica realizada a partir do desenvolvimento da Pesquisa-formação, envolvendo professores/as da roça de classes multisseriadas. A pesquisa-formação foi atravessada pelos princípios da fenomenologia e da hermenêutica a fim de investigar, através das histórias de vida-formação, de que maneira a cultura afro-brasileira emerge das narrativas de professoras e professores de classes multisseriadas das escolas rurais no município de Itiúba. Partindo desse pressuposto, a fenomenologia auxiliou na busca dos sentidos atribuídos à diversidade e educação para a relação étnico-racial, suscitando um posicionamento reflexivo diante do

\footnotetext{
1 O termo roça é entendido aqui a partir da concepção de Rios (2011, p. 13), tomando como uma “'ruralidade específica’ envolta, principalmente, na semiótica da terra".

2 Evidentemente, essa perspectiva caótica não é exclusiva da educação rural, no entanto a situação se revela mais agravada, pois como alerta Silva (2003, p. 29): “além de não se considerar a realidade onde a escola está inserida, a mesma foi tratada sistematicamente, pelo poder público, com políticas compensatórias".
} 
que se revela a partir da interação firmada com o 'outro', fazendo irromper desse vínculo o encoberto e contido.

Esse estudo é um lugar em que as histórias de vida, formação e profissão docente em contextos rurais ganharam centralidade, sobretudo, por que estão imbricadas e assinaladas por uma mestiçagem de vozes silenciadas no sertão baiano. Neste sentido, metaforicamente os/as docentes teceram aqui um "tapete" de experiências de vida, com o propósito de trabalhar com a reflexividade biográfica construída a partir das categorias fundantes deste trabalho que são: a identidade, a cultura afro-brasileira e à docência em classes multisseriadas.

\section{IDENTIDADE NEGRA: ENTRE NEGAÇÕES E INVISIBILIDADES}

A identidade negra no Brasil de hoje constitui um contexto do qual tanto se debate, no entanto em uma celeuma que, muitas vezes, pouco define a amplitude em que consiste o referido temário. Uma vez que, alcançar a consciência da negritude significa ter vivenciado experiências de invisibilidades, tendo no percurso de formação identitária ("si mesmo"), perspectivas confundidas, sendo conduzido sutilmente a expectativas de negação, pois em uma sociedade como a nossa, é certo os procedimentos de exclusão. E nessa conjuntura a identidade negra, como parafraseia Ciampa (1998, p. 16) é "morte-e-vida [...] um outro nome para identidade". É morte, mas, é também, e, sobretudo, vida expressa naquele/a que se empenhou a escrever uma outra história, com cores vivas, festivas e vibrantes de quem passa pelo processo de reconstrução da identidade. Afinal de contas, os/as negros/as cruzaram suas histórias com as histórias daqueles/as que já estavam por aqui. Trouxeram, entre outras coisas, seus traços étnicos, suas ciências, tecnologias, identidades e culturas que foram entalhadas nas relações de poder, resistência e diferenças.

Saber-se negra é viver a experiência de ter sido massacrada em sua identidade, confundida em suas perspectivas, submetida a exigências, compelida a expectativas alienadas. Mas é também, [...], a experiência de comprometer-se a resgatar sua história e recriar-se em suas potencialidades (SOUZA, 1983, p. 17-18).

A superação dessa configuração exige uma longa caminhada, no intuito de criar oportunidades de diálogo sobre os desafios do ser negro e ser negra, ampliando sua consciência de identidade, reconhecendo o chão que pisa. Diante desta realidade, não se poder calar, pois o silêncio oculta o racismo brasileiro, instituindo e legitimando o silêncio institucional, o silêncio individual, o silêncio público e o silêncio privado. Silêncio que nos alcança e nos habita, convencendo-nos, por vezes, da pretensa cordialidade nacional e do elegante mito da democracia racial. Mito que se ergueu e se faz vigente como representação 


\section{RELACCÕES ÉTNICO-RACIAIS NA DOCÊNCIA EM CLASSES....}

idealizada de nossa sociedade, sinalizando a construção de uma sociedade amistosa, tolerante e inclusiva. Mito que exercita, no cotidiano, o engano e a ilusão, escondendo sutilmente a enorme e perversa desigualdade racial do país. Lamentavelmente, o poder de ocultamento desse mito consolidou-se em nosso senso comum e, desavisados, negamos a desigualdade e o racismo.

Ter o conhecimento desta trama é o primeiro passo para desatar esse entrelaçado perigoso. De tal modo, é importante que o negro conheça a conjuntura da qual ele está inserido, ou melhor, excluído. Tomando posse do seu verdadeiro lugar, que não é sendo melhor que o branco e nem o eliminado de todo e qualquer processo decisório, lançando mão de uma consciência que funcione como um trampolim para reais conquistas. Por isso, a sociedade brasileira daquela época, formava-se com a presença maciça de negros/as escravizados/as que constituíam o último lugar numa pirâmide social e mantiveram-se inferiorizados/as nesta organização. Tal é o paradoxo que "a mestiçagem, que aparentemente aproxima e une, vem ferir o indivíduo negro que não corresponde ao tipo ideal, o qual, [...], supõe a exclusão e a denegação da identidade" (D’ADESKY, 2009, p. 69). Do mesmo modo, que se percebe, ainda hoje, o surgimento de mitos, estereótipos e neuroses, bem como respingos históricos de uma subalternidade negra.

Sabemos que o Brasil é um país culturalmente heterogêneo e diverso, visto que se formou por intermédio de situações contraditórias em que entendimentos e graves divergências se atravessaram, provocando o hibridismo cultural, a mestiçagem, a crioulização e o sincretismo. Não iremos desenvolver, de maneira minuciosa, os respectivos conceitos, mas apenas, reportando-nos a Canclini (2013, p. 29) ao ressaltar que embora os conceitos sejam legítimos, quando se pretende abordar questões específicas e referentes às relações raciais, a fusão de línguas e a mistura de práticas religiosas não seriam suficientes “[...] para especificar formas particulares de hibridação mais ou menos clássicas".

Por certo, não é tão simples explicar o processo de hibridização ocorrido aqui no Brasil, pois a sua formação deu-se em meio ao colonialismo e os benefícios financeiros, agrupações sincréticas arbitrárias, perdas e reconstituições identitárias e também pelos mecanismos de aculturação, responsáveis pela adaptação social diante de tamanha miscelânea. Enfim, é ainda o Brasil, um país em que prevalece a forma de preconceito, baseado na origem racial através de uma profusão de manifestações preconceituosas e discriminatórias relacionadas aos fenótipos, isto é, as nuances da cor da pele, o tipo de cabelo, o formato do nariz e boca, entre outras particularidades perceptíveis e hereditárias que caracterizam uma pessoa ou uma linhagem, como por exemplo nas expressões 'corpo negro 
fisicamente sujo', 'feio', 'torrado'. 'Negro de cabelo duro', 'pixaim', 'bombril'; 'boca de caçapa', 'beiço de capote' e 'nariz de nó de peia' etc.

Tais questões reportam-nos a um ponto específico do memorial formativo ${ }^{3}$ da professora Clementina de Jesus ${ }^{4}$ quando, recordando passagens de sua infância e particularidades da relação familiar, ela compartilha: "Lembro-me bem que o meu pai, negro forte e não muito alto, bundudo de pernas com batatas grossas, chamava-nos de cabelos de engaço (engaço naquele tempo era a carcaça do cacho de ouricuri). Acredito que era uma forma de desabafo quando estava irritado com a gente [...]”. Clementina de Jesus no ato de rememoração e partilha sobre a maneira como o seu pai se referia aos seus cabelos e os das irmãs como 'cabelos de engaço', rapidamente "engatilha" um atenuante, como uma voz que, em algum momento, parece, consciente ou inconscientemente, querer ora atenuar, ora remir as faltas cometidas por outrem.

O fato é que se nos atentarmos a explicação da professora para a palavra 'engaço', descrito entre parênteses, descobriremos que se trata da ramificação seca que sustenta os frutos do ouricuri, assim como as ramificações que sustentam as uvas nos cachos. Porém, para a primeira ilustração o cacho é muito mais denso e com emaranhados de ramas bem mais compridas, desalinhadas e ressequidas (quando não tem fruto) do que a segunda ilustração. Trocando em miúdos, o pai da professora Clementina, diante de um acesso de raiva, pretendia descompor as suas filhas através dos cabelos crespos. Afinal, conforme Gomes (2010, p. 138):

$\mathrm{Na}$ escravidão o tipo de cabelo e a tonalidade da pele serviam de critérios de classificação do escravo e da escrava no interior do sistema escravista, ajudando a definir a sua distribuição nos trabalhos do eito, nos afazeres domésticos no interior da casa-grande e nas atividades de ganho. Assim, na relação senhor-escravo esses dois elementos passaram a ser usados como os principais definidores de um padrão estético em relação aos negros.

\footnotetext{
3 Os memoriais são oriundos das histórias de vida e da trajetória profissional desses/as professores/as, provenientes do Ateliê (auto)biográfico desenvolvido ao longo da Pesquisa Formação que compôs uma das etapas da elaboração desta pesquisa.

4 Para evitar possíveis constrangimentos ou qualquer situação vexatória na publicização das histórias/narrativas de vida foi mantida a confidencialidade dos seus respectivos nomes, substituindoos por nomes de homens e mulheres negros que notadamente entregaram suas histórias individuais para a resistência negra e, por consequência, tornaram-se emblemáticos exemplos contra a escravidão e a colonização do passado.
} 
Apesar do pai da professora Clementina ser negro, como ela mesma enfatizou por todo o detalhamento físico, ainda assim, ele passou a propagar e atestar, ainda que de maneira obtusa, a inferioridade racial do negro por meio do cabelo crespo das filhas. No entanto, o enfoque dessa reflexão é tomado a partir da compreensão desse episódio através da perspectiva da professora que, reconhecendo as características da raça negra no seu progenitor, identifica no crespo dos seus cabelos, respingos da herança racial negra. Entretanto, ao tentar abrandar e mitigar o conteúdo do discurso do pai, Clementina ignora a naturalização da expressão racista que permeando as relações e impregnando as estruturas étnico-raciais, reproduziu no seu próprio inconsciente a abstração de que tudo parece normal, deteriorando a percepção de que, como o pai, também incorpora expressões com carga pejorativa quando se refere ao povo negro.

Obviamente esse impulso aviltante vem determinado e comprovado pela ideologia do branqueamento, isto é, a maneira de pensar a partir da égide do racismo, ditando a regra de que o que é apropriado e formoso é branco e tudo o que pernicioso é negro, estabelecendo, desse modo, a supremacia de uma aparência física mais próxima da raça caucasiana, as feições comuns a todos os europeus, na qual se destaca o cabelo, e exerce a impiedosa tendência que atrofia a identidade do/a negro/a.

[...] o sujeito negro [...], através da internalização compulsória e brutal de um Ideal de Ego branco, é obrigado a formular para si um projeto identificatório incompatível com a propriedades biológicas do seu corpo. Entre o Ego e seu Ideal cria-se, então, um fosso que o sujeito negro tenta traspor, às custas de sua possibilidade de felicidade, quando não de seu equilíbrio psíquico (COSTA, 1983, p. 3).

Sendo assim, o/a negro/a considerado/a uma raça bárbara, vítima da opressão e dos efeitos da alienação e hipnotizado pelo fetiche do branco, ele, o negro, ver-se condenado a negar tudo aquilo que contradiga o mito da brancura. Portanto, o caráter dúbio e ambíguo do mestiço, revela-nos a existência do preconceito que 'tolera' a mestiçagem considerando, no processo de hibridização do negro com o branco, a possiblidade de se tornar 'agente de civilização', pois “quanto mais o negro se aproximar do branco pela tez, pelos traços do rosto, nariz afilado, cabelos lisos, lábios finos, maiores as suas possibilidades de ser aceito" (BASTIDE; FERNANDES, 1959 apud GOMES, 2010, p. 146).

Indubitavelmente, a população negra tem sido imolada por uma profusão de imagens negativas forjadas em diferentes tempos, espaços e meios, ocasionando a privação e violação dos seus direitos. E foi a essa profusão que, ainda criança, o professor Luís Gama esteve submetido: “[...] sempre ouvia algumas brincadeiras de mau gosto com negros, como: [...] 'negro não é gente', 'negro quando não suja na entrada, suja na saída' entre outras formas 
de discriminação". O professor reconhece no seu discurso que tais "gracejos" por ele presenciado, significam injúrias abusivas que expõem o verdadeiro rosto do racismo, muito embora esteja mascarado pelo artifício sutil da chacota e deboche com é o caso do provérbio de uso quotidiano 'negro não é gente', afinal, como denuncia Fanon (2008, p. 182), negros são “homens-máquinas-animais". Era essa máxima também alardeada pelo Racismo Científico e outras correntes de pensamentos racistas lá do século XIX que pretendiam justificar o projeto de interferência na reprodução humana, para eliminar raças ditas inferiores, pois para estes cientistas só com uma casta pura é que uma nação teria condições de desenvolver-se.

As ideias racistas e deterministas das Teorias Raciais foram bem acolhidas e introduzidas no Brasil no fim do século XIX e permaneceu de maneira vigorosa até o fim da Primeira República em 1930. Os discursos racistas travestidos de cientificidade foram apregoados e legitimados por instituições brasileiras de renome que associavam ao/à negro/a ou mestiço/a a 'indolência', a 'inferioridade' racial, a 'degenerescência' e as mazelas da nossa sociedade. As epidemias, os transtornos psiquiátricos e criminalidades eram todos oriundos de uma raça de traços e anatomia bestial e selvagem, corrigir esse equívoco era necessário para alavancar o país.

No inconsciente coletivo, negro $=$ feio, pecado, trevas, imoral. Dito de outra maneira: preto é aquele que é imoral. Se, na minha vida, me comporto como um homem moral, não sou preto. Daí se origina o hábito de se dizer [...], do branco que não presta, que ele tem uma alma de preto. [...] A cor de sua pele [...], é negra. Todos os mal-entendidos provêm deste quiproquó (FANON, 2008, p. 163).

A percepção trazida por Frantz Fanon demostra o quanto a imagem do/a negro/a é menosprezada, ademais torna público o raciocínio inadequado que interioriza o negro no calabouço do 'inconsciente coletivo'. Tal circunstância alcança tanto o/a branco/a quanto o próprio negro/a, ambos/as memorizam a má concepção e registram o estado de inferioridade, pobreza e miséria, ignorando e evitando a história que ajuda a compreender essa opressão vitimizadora da população negra como resultado de algo que se iniciou num sistêmico processo, transpassado por todos esses séculos. Essa conjuntura subalternizada que embaraça a negritude diante das representações depreciativas, irrompe também no discurso da professora Carolina de Jesus.

Meu avô era um senhor alto, branco e muito rígido. Minha avó uma senhora religiosa, branca, mandona e de poucos afetos. Os dois tiveram oito filhos, sendo quatro homens e quatro mulheres, uma dessas mulheres é negra. Muitos familiares comentavam que os próprios pais a tratavam de maneira diferente, as reclamações e o trabalho era sempre maior para ela. 
Lembro-me de um dia que vivenciei minha vó cuspindo dentro de um prato de comida e pedindo para minha tia fazer novamente, pois ela não fazia nada que prestava. Minha tia saiu chorando para cozinha sem dizer nada. Eu, uma criança, fiquei perplexa me perguntando porque ela era tão passiva e não reagia aquela situação. Minha tia cuidou deles até o final de suas vidas, atualmente ela mora sozinha, não casou e não teve filhos.

As memórias da Professora Carolina integram resquícios do tempo escravista, em que 'trabalhar é pra negro', em que se estabelece ao pretume da cor o rançoso contexto servil onde o negro era a 'besta de carga'. A tia negra preterida pela mãe, enxovalhada pelos escarros da indignidade e degradação representa com exatidão o que Fernandes (1972, p. 207) chama de "o mais baixo status da hierarquia social". O autor nos oferece ainda um fragmento de como o folclore brasileiro compila e confirma, em sua tradição oral, a existência desse paralelismo através do trocadilho racista que diz: “O negro é burro de carga // O branco é inteligente / / O branco só não trabalha / / Porque preto não é gente” (FERNANDES, 1972, p. 206).

Definitivamente o dimensionamento da questão racial é atravessada pelo imaginário popular, passando pela literatura indo para à educação, tornando-se, em alguns casos, um depositório fecundo do típico pensamento racista à brasileira. Nesses casos, é possível aprender a ultrajar, repulsar, restringir, contradizer com propósito, intento e ânsia terminantemente por causa da raça, cor, origem, nacionalidade, gênero, geração, sexo e crenças. Por conseguinte, não se pode enxergar tal situação como apenas uma maledicência, um deslize ou engano mal compreendido, pois no fim das contas a reprodução jocosa e deliberada produz um enfeito perverso. Durante muito tempo, a inexistência de uma reflexão na educação brasileira acerca das relações raciais, por exemplo, no planejamento escolar, impossibilitou a promoção de relações interpessoais respeitáveis e equânimes entre aqueles/aquelas que compõe o cotidiano da escola.

Com relação aos alunos negros, ressalta-se que há uma nítida associação entre apelidos e a referência à inscrição racial. Ao se referir à cor da pele através dos apelidos, se destacam marcas raciais, traços de identificação de um determinado grupo racial, mecanismos que vão permitir $\mathrm{o}$ enquadramento do sujeito objetificado. Alunos negros são constantemente reduzidos em sua nominação a características e metáforas que possam circunscrevê-los racialmente (GENTILI, et al, 2011, p. 15).

Essa indiferença no tocante à influência que o racismo, o preconceito e as discriminações raciais têm nas diversas instituições educacionais, favoreceu a afirmação dos fenótipos enquanto diferenças entre negros e brancos, compreendidos como desigualdades naturais. Mais do que isso, engendraram os negros de acordo com sinônimos chulos. Por consequência, o silenciamento da escola com relação ao racismo habitual não só atravancou 
a aprendizagem de alunos/as negros/as e brancos/as nas escolas brasileiras, como também os abruteceram, impedindo-os de serem pessoas verdadeiramente libertas das hostilidades, dos preconceitos, dos estereótipos, dos estigmas, entre outras mazelas.

[...] a existência do racismo, do preconceito e da discriminação raciais na sociedade brasileira e, em especial, no cotidiano escolar acarretam aos indivíduos negros: auto-rejeição, desenvolvimento de baixa auto-estima com ausência de reconhecimento de capacidade pessoal; rejeição ao seu outro igual racialmente; timidez, pouca ou nenhuma participação em sala de aula; ausência de reconhecimento positivo de seu pertencimento racial; dificuldades no processo de aprendizagem; recusa em ir à escola e, conseqüentemente, evasão escolar. Para o aluno branco, ao contrário acarretam: a cristalização de um sentimento irreal de superioridade, proporcionando a criação de um círculo vicioso que reforça a discriminação racial no cotidiano escolar, bem como em outros espaços da esfera pública (CAVALLEIRO, 2005, p. 12).

As reflexões apresentadas pela autora remetem-nos ao passado, onde é possível identificar a precariedade da escolarização dos negros brasileiros, pois é certo que olhando o passado, entendemos aquilo que o presente revela com veracidade. Afinal, eram os negros/as sobretudo os/as africanos/as escravizados/as, proibidos/as de aprenderem a ler e escrever, sendo impedidos/as de frequentarem as escolas, quando estas existiam. E se tivessem a permissão e o "privilégio" de terem os/as seus filhos/as acesso as lições catequéticas dos jesuítas, seria apenas com o intuito de mantê-los submetidos ao austero controle de seus senhores missionários, portanto um propósito muito distante de algo que objetivasse efetivamente a mudança do destino dos cativos.

Assim, estabeleceu-se para os/as negros/as e mestiços/as um processo contraditório de 'inclusão e exclusão’ à cidadania brasileira, isso por intermédio da educação. Inclusão pelo princípio da igualdade republicana, mas na prática imperavam as ressalvas, pois a educação definia a instrução necessária para a participação efetiva da cidadania, tal como o direito ao voto. Por não estarem os/as ex-escravizados/as inseridos/as na cultura letrada, visto que não havia um sistema escolar para todos, negavam-lhes a real liberdade e igualdade. Esse acesso diferenciado a cidadania brasileira, significava, entre outras coisas, a consolidação das desigualdades sociais. Diga-se de passagem, desigualdades relativas à educação que teve como consequência as dificuldades dos negros e seus descendestes de encontrarem dignidade a parir da conquista de emprego, renda e maior qualidade de vida. 


\section{EDUCAÇÃo E RELAÇÕES ÉTNICO-RACIAIS: A LEI No 10.639/20035}

No que se refere às relações étnico-raciais, a história e a educação sempre estiverem interligadas no processo de negação e afirmação construídas para e pelos/as negros/as. Estes/Estas não fazendo parte do universo letrado não se resignaram com a exclusão que lhe foi imposta, organizando movimentos de luta e resistência ao longo da história. Os negros conquistaram o direito ao trabalho livre, o direito ao livre culto de suas religiões, o direito de constituir família, de viver fora de tutelas. A luta, contudo, se assentou pelo viés da autoafirmação e honra de ser negro/a.

Sendo assim, a educação formal, estabelecia-se como marco no panorama das reivindicações do Movimento Negro, constando nas pautas de lutas os esforços em denunciar e destacar a carência de diretrizes que objetivassem a orientação e a formulação de projetos comprometidos na valorização da história e cultura dos afro-brasileiros e dos africanos, como também propusessem o envolvimento com as práticas pedagógicas a partir das relações étnico-raciais positivas a que tais conteúdos devem encaminhar. Coerentemente com o protagonismo negro no cenário político e em suas estratégias de promover uma educação antirracista, o Estado brasileiro vem formulando ações no sentido de prover políticas e programas para valorização da identidade e cultura dos povos negros, assinalando um quadro de intenções que visam a erradicação do racismo e da discriminação racial, pois de acordo como o grifo de Cavalleiro (2006, p. 16):

A partir da III Conferência Mundial contra o Racismo, a Discriminação Racial, a Xenofobia e as Formas Correlatas de Intolerância, realizada em Durban, África do Sul, de 31 de agosto a 7 de setembro de 2001, esse procedimento é mantido, sendo o Estado brasileiro signatário da Declaração e do Plano de Ação resultantes desta conferência.

5 A Lei 10.639/2003 alterou a LDB (Lei Diretrizes e Bases) $n^{\circ} 9.394 / 1996$, passando a vigorar acrescida do art. 26-A que tornou obrigatório nos estabelecimentos de ensino fundamental e médio, oficiais e particulares o ensino sobre História e Cultura Afro-Brasileira.

$\int 1^{\circ} \mathrm{O}$ conteúdo programático a que se refere o caput deste artigo incluirá o estudo da História da África e dos Africanos, a luta dos negros no Brasil, a cultura negra brasileira e o/a negro/a na formação da sociedade nacional, resgatando a contribuição do povo negro nas áreas social, econômica e política pertinentes à História do Brasil.

$\int 2^{\circ}$ Os conteúdos referentes à História e Cultura Afro-Brasileira serão ministrados no âmbito de todo o currículo escolar, em especial nas áreas de Educação Artística e de Literatura e História Brasileiras. [...] Art. 79-B. O calendário escolar incluirá o dia 20 de novembro como 'Dia Nacional da Consciência Negra' (BRASIL, 2005, p. 35). 
Por isso, com a publicação da Lei no 10.639/2003 reconhece-se a necessidade de se inserir ações afirmativas no currículo oficial da rede de ensino, estabelecendo a obrigatoriedade do ensino de História e Cultura Afro-Brasileira e Africana na Educação Básica. Assim, deve-se levar em conta que, conforme sinalizam os Parâmetros Curriculares Nacionais (1997, p. 41):

Embora tenha sido muito salientado o papel de reprodutora de mecanismos de dominação e exclusão, atribuídos historicamente à escola, cabe lembrar que potencializar suas possibilidades de resistência e transformação depende também, ainda que não exclusivamente, das opções e das práticas dos educadores.

Compreendemos que a educação como um direito que garante acesso a outros direitos, tem a missão de disseminar o respeito e a promoção da equidade humana em resposta a lei que nos garante a igualdade, repudiando a distinção de qualquer natureza, assegurando a inviolabilidade do direito à vida, à liberdade, à igualdade, à segurança e à propriedade (Art. $5^{\circ}$, do capítulo $1^{\circ}$, dos direitos e deveres individuais e coletivos Constituição da República Federativa do Brasil). Sendo, obrigação do Estado proteger as manifestações das culturas populares, indígenas e afro-brasileiras e dos demais agrupamentos inseridos no processo civilizatório nacional (Art. 215, seção II da cultura, inciso primeiro da atual Constituição da República Federativa do Brasil).

Com relação a lei no 10.639, é importante esclarecer que ela determina a inclusão e permanência, no currículo oficial da rede de ensino, a obrigatoriedade da efetivação do temário "História e Cultura Afro-Brasileira”. Bem como, a Lei 11.645, sancionada no dia $1^{\circ}$ de março de 2008, que obriga os estabelecimentos de ensino da rede particular e pública inserir o estudo da "História e Cultura dos Povos Indígenas do Brasil". Sendo assim, reconhecendo e valorizando a contribuição cultural, histórica, científica dos/as negros/as e índios, com sua maneira de ver e interagir com o mundo. De fato, essas leis configuram-se como um ganho, mas sobre tudo, como uma conquista resultante da atuação histórica dos movimentos sociais.

Já se passaram mais de dez anos da promulgação da lei no 10.639, tempo suficiente para reconhecer que muito vem sendo desenvolvido e recriado por diversas pessoas, em distintos lugares do Brasil, avançando no sentido da promoção de reais transformações nas relações sociais em prol da igualdade racial. Com vistas a tornar as disposições legais prescritas pela referida lei, foram desenvolvidas ações, experiências e práticas inovadoras efetivadas por professores/as, gestores/as, estudantes e familiares comprometidos com a melhoria da qualidade da educação, e, para tal, enfrentaram as inúmeras dificuldades tão 
presentes no processo da educação brasileira. O fato é que, a consequência se materializou em exitosas estratégias elaboradas e divulgadas em redes de troca e apoio, apontando novos caminhos e direções, alimentando a crença por um Brasil mais justo para todos e todas. No entanto, é preciso continuar adotando iniciativas que visem, em especial, à formação continuada dos/as docentes da educação básica para que possam superar os desafios impostos às suas práticas pedagógicas a partir da lei 10.639 .

No que se refere à formação de professores/as as Diretrizes Curriculares Nacionais para a Educação das Relações Étnico-Raciais e para o Ensino de História e Cultura AfroBrasileira e Africana, em um dos seus encaminhamentos, refere-se à introdução da formação de professores/as pelas seguintes perspectivas:

Introdução, nos cursos de formação de professores e de outros
profissionais da educação: de análises das relações sociais e raciais no
Brasil; de conceitos e de suas bases teóricas, tais como racismo,
discriminações, intolerância, preconceito, estereótipo, raça, etnia, cultura,
classe social, diversidade, diferença, multiculturalismo; de práticas
pedagógicas, de materiais e de textos didáticos, na perspectiva da
reeducação das relações étnico-raciais e do ensino e aprendizagem da
História e Cultura dos Afro-brasileiros e dos Africanos (BRASIL, 2005, p.
23).

Por isso, a formação de professores/as deve ser encarada como uma das principais metas das políticas públicas governamentais, bem como das ações empreendidas por instituições de fomento educacionais. Nesse sentido, a narrativa do professor Luís Gama ratifica e denuncia a segregação dos estudos referentes as relações étnico-raciais quando ele, rememorando, afirma que: “[...] durante toda minha formação, não foi abordado, nas instituições que estudei, sobre a identidade e a cultura afro-brasileira". Tal omissão, concernente ao estudo da identidade e cultura afro-brasileira, ganha longevidade deixando o passado para se instalar também no presente das salas de aula de professores/as que não conseguem fazer de suas práticas pedagógicas, exímias oportunidades para o desencadeamento de processos afirmativos das identidades e da historicidade negada, tal como distorcida do povo negro.

Meus avós paternos eram negros de traços bem chegados ao povo africano [...]. Minha família é negra, alguns mais outros menos, contudo não havia conversas entre eles sobre a negritude, apenas se consideravam com eram [...]. Mas, em todo esse tempo [ensino fundamental] eu não ouvi falar em cultura africana ou cultura afrodescendente, foi um discurso sobre o qual não tive acesso. [...] no segundo grau, ouvi falar um pouco sobre a cultura negra, porém ainda não compreendia sobre o assunto. Depois que 
terminei, fiz o vestibular da UNEB $2000^{6}$, [...] só assim tive a oportunidade de conhecer e estudar a cultura afrodescendente e também passar um pouco para os meus alunos, mesmo assim não foi um estudo que me deu segurança para trabalhar especificamente com essa cultura. (Professor Milton Santos)

A fala do professor Milton Santos, além de coadunar com o depoimento do professor Luís, no aspecto da abordagem da questão racial como algo 'sobre o qual não se teve acesso' e quando se teve fora de maneira insipiente, também nos endereçou a afirmação de Nóvoa (2003 apud NETA, 2012, p. 295) quando diz que “[...] ser professor implica um corpo-a-corpo permanente com a vida dos outros e com a nossa própria vida. Implica um esforço diário de reflexão e de partilha", pois o espaço escolar impõe desafiantes instigações tanto para o/a aluno/a quanto para o/a docente. São provocações que despontam na rotina de nossas escolas, pressupondo que $\mathrm{o} / \mathrm{a}$ docente tenha que se servir das suas salutares experiências de vida, mas que são insuficientes. Por conseguinte, tornar-se necessário a ampliação continua da nossa condição de aprendentes, dispondo-nos a conhecer melhor o mundo, a nós mesmos e os outros.

Definitivamente, ainda é preciso investir maior esforço para que seja possível realizar um significativo salto no intuito de minorar o fosso histórico, responsável, entre tantas coisas, pela ausência de qualidade na educação dos/as negros/as no Brasil, pois quando se analisa o povo negro, no campo educacional, sua desvantagem também é destacada, o que condiciona seu estatuto de cidadania como de 'segunda classe'. Esse déficit educacional entre negros/as e brancos/as, revelando-nos um índice elevado de cidadãos/ãs negros/as que, na contemporaneidade, tem dificuldade no acesso e permanência na escola, assumindo o caráter de excluídos/as. Logo, o que pretende a lei no 10.639 é devolver o direito dos/as negros/as de se reconhecerem partícipes da cultura nacional, expressando livremente suas próprias concepções de mundo, manifestando com autêntica autonomia seus pensamentos.

Isto é, os/as descendentes de africanos, europeus, asiáticos e dos povos indígenas precisam encontrar na escola condições de terem suas histórias, culturas, identidades reconhecidas e valorizadas. Nesta perspectiva, a escola deve ser produtora de conhecimentos e divulgadora de atitudes, posturas e valores que se proponham integrar todos e todas, igualmente, respeitando o direito a alteridade e rompendo com a prática que, muitas vezes, insiste na negação do 'outro’ como ser humano. Isso exigirá condições materiais das escolas

6 O Programa REDE UNEB 2000 é como ficou popularizado o Programa Intensivo de Graduação desenvolvido pela UNEB desde 1998, em parceria com as prefeituras municipais de várias regiões do Estado da Bahia. 


\section{RELACCÕES ÉTNICO-RACIAIS NA DOCÊNCIA EM CLASSES....}

e formação adequada dos/as professores, portanto, aspectos indispensáveis para uma educação de qualidade. Desse modo, em quais condições estará o/a docente diante do compromisso em corresponder ao cumprimento de leis importantes como a de $\mathrm{n}^{\circ}$ 10.639/2003? Como estabelecer novas maneiras de trabalhar as relações étnico-raciais, contribuindo com a valorização da cultura negra como forma de fortalecer os sujeitos negros?

Desse modo, será preciso, antes de conclamá-los/as a incorporarem a luta pela dignificação do/a negro/a da roça e da cidade, oportunizar momentos formativos que façam esses/as docentes se inscreverem nas tramas de suas histórias de vida, por meio de uma dinâmica prospectiva que reúna o passado, o presente e o futuro, visando fazer emergir um novo projeto pessoal e profissional, reconhecendo-se como um dos sujeitos partícipes da nação brasileira, a fim de desvelar o racismo sutil, porém ainda tangível na sociedade e na educação brasileira.

\section{RELAÇÕES ÉTNICO-RACIAIS E PRÁTICA DOCENTE}

Um dos objetivos da pesquisa-formação realizada para fundamentar esta pesquisa, foi inserir os/as professores/as em alguns debates indispensáveis para a compreensão da categoria teórica identidade e cultura afro-brasileira. E para tal, foi necessário auscultar primeiro a história do negro/a passando pela África gloriosa e seus reinos, civilizações e cidades antigas, apresentando, dessa forma, o continente africano como 'Berço da Humanidade' a partir de suas contribuições para as ciências modernas. Mas, também foi necessário analisar o início da exploração do continente africano, a diáspora dos povos negros, a rota da migração e a chegada dos/as africanos/as escravizados/as ao Brasil Colônia. O referido projeto, intitulado de 'VEJAM COMO SOMOS PRETOS, PRETA, PRETINHA', foi aplicado pelos/as professores/as em suas turmas multisseriadas, por isso teve os seus desdobramentos correspondentes as especificidades pedagógicas da multisseriação. Com relação à aplicação do mencionado projeto, relatou a professora

\section{Francisca:}

Os alunos mostraram não conhecer quase nada referente a África, ou seja, uns nem sabiam nada. Alguns tinham em mente que era um país de onde vieram os negros escravizados e que lá só existia pobreza. Minha maior dificuldade foi quando começamos a falar dos negros que foram escravizados, pois o preconceito por parte dos alunos ainda é muito grande, principalmente quando se toca no assunto. 
É importante salientar que as formas de discriminação e preconceito de qualquer natureza não têm o seu nascedouro na escola, porém o racismo, as desigualdades e discriminações correntes na sociedade perpassam por ali, por isso a professora Francisca expõe a situação dando ênfase a questão que, entre outras razões, é decorrente do desconhecimento ou insipiência de determinados conhecimentos. Para que as instituições de ensino desempenhem a contento o papel de educar, é necessário que se constituam em espaço democrático de produção e divulgação de conhecimentos e de posturas que visam a uma sociedade justa. Pensando nessa perspectiva declara a professora Carolina:

Acredito na escola que transforma vidas. Por isso faço questão de trabalhar temas que ajudem nas reflexões, desenvolvendo nos estudantes o seu pensar e o seu escutar. A semana que trabalhei com esse projeto, foi vivenciada posturas e atitudes surpreendentes. Fiquei emocionada com alguns discursos. Mas, também chocada, pois quando se fala de algo que envolve pessoas parte para o lado das emoções, onde todos querem falar algo que viveu sobre o assunto. Então, depois de uma atividade um aluno fez a seguinte declaração: "Eu acho que os negros são feios. E eu tenho coragem de dizer. Tem gente que finge para ser educado".

Definitivamente, o discurso do aluno da professora Carolina, coloca-o na condição de vítima de uma história brasileira forjada, onde os heróis, ou melhor, os principais personagens são marcadamente branco-europeus. A utilização de recursos pedagógicos com esse caráter remonta a um processo de socialização racista e etnocêntrico, em detrimento da historicidade dos/as negros/as que tem subtraída, da história oficial, suas lutas de resistências, os registros das genuínas contribuições na produção das riquezas do Brasil e os conhecimentos advindos dos/as negros/as africanos/as.

[...] em geral, apresentam apenas pessoas brancas com e como referência positiva, também são ingredientes caros ao processo discriminatório no cotidiano escolar. Quase sem exceção, os negros aparecem nesses materiais apenas para ilustrar o período escravista do Brasil-Colônia ou, então, para ilustrar situações de subserviência ou de desprestígio social (CAVALLEIRO, 2005, p. 13).

Por isso, a lei federal no $10.639 / 2003$, entre outras orientações, alerta sobre a inclusão das histórias dos quilombos, a começar pelo de Palmares, e de remanescentes de quilombos, oportunizando a construção de uma imagem positiva do povo negro a partir da história brasileira, superando a visão de passividade tão difundida, evidenciando as muitas formas de resistência negra ao longo dos séculos.

A história oficial não registra esses fatos gloriosos, [...]. Em consequência dessa ocultação da verdade, a juventude da América desconhece os seus poderes potenciais e a sociedade negra lamenta uma história frustrante e sem epopéia (ASETT, 1986, p. 17). 


\section{RELAÇÕES ÉTNICO-RACIAIS NA DOCÊNCIA EM CLASSES....}

Apesar de uma crescente difusão, nos últimos tempos, de estudos e pesquisas relacionadas ao negro no Brasil, infelizmente ainda quase que todas não consideraram a ascendência africana, desmerecendo o passado historiográfico da África, remetendo-o ao mais completo esquecimento. A educação brasileira, principalmente no passado, não se mostrou suficientemente solidária com a historiografia africana, visto que por muito tempo foi desconsiderado ou postergado no currículo oficial o estudo da História da África précolonial, isto é, o tempo antes da colonização europeia. Tal hesitação comprometeu e maculou a compreensão da sociedade brasileira acerca da imensa riqueza e importância cultural, simbólica e tecnológica que advém do continente africano, tendo fornecido, inclusive, condições para o desenvolvimento de comunidades e outras regiões (fora da África) em que se estabeleceu a combinação de elementos identitários de forma complexa e sui generis.

Os povos se tornaram sem cultura, sem história, sem identidade e mergulhados na bestialidade. Reinos e impérios foram substituídos por imagens de hordas e tribos primitivas em estado de guerra permanente, umas contra as outras, para justificar e legitimar a missão pacificadora da colonização dessas sociedades, ora em diante qualificadas como ignorantes e anárquicas. A exploração e a dominação brutal às quais foram submetidos os africanos exigiam que fossem considerados como brutos. Para justificar e legitimar a violência, a humilhação, os trabalhos forçados e a negação da humanidade dos africanos, era preciso bestializar a imagem desses homens e mulheres (MUNANGA; GOMES, 2006, p. 28).

Ainda hoje, as imagens que são apregoadas sobre o continente negro sucumbem os vestígios de um palácio real, dos seus reis, de um império, das formas políticas de organização baseadas em clãs, linhagens e parentescos, ou de uma cidade moderna africana, com seus edifícios, estradas, pontes, portos, empresas e minerações, contribuições do ex-colonizador. Muito pelo contrário, são imagens que nos alcançam, vindas em diferentes veículos, suficientemente capazes de minimizar todo legado histórico e toda sabedoria produzida há milhares de anos por autênticos e distintos povos africanos. É importante salientar que não se trata de constituir um outro etnocentrismo, substituindo a perspectiva europeia pela africana, muito pelo contrário, pois as diretrizes apontam para a ampliação da diversidade cultural, racial, social e econômica brasileira. O que se pretende com o estudo da História e Cultura Afro-Brasileira e Africana é desfazer o equívoco que, costumeiramente, descortinou o continente africano como um território deturpado, desmantelado e desbaratado.

É preciso que seja refletido com os/as alunos/as que a atual situação da África é algo historicamente desejado, porém encoberto. Não é à toa a sua colocação na 'periferia' desse 
mundo tecnologicamente desenvolvido e que esteja reduzida por um afã expansionista caracterizado pelo capitalismo e por toda forma de exploração dos recursos naturais e humanos. Por isso, não podemos desconsiderar que o continente africano, esteve "na vanguarda do progresso durante os primeiros 15.000 séculos da história do mundo, desde o australopiteco e o pitecantropo. A 'Mãe negra' que sofre e chora com tanta negação, abusos e redução a condição de "utensílio" é a mesma que desempenhou um papel fecundante no alvorecer da humanidade.

[...] nas imagens que são veiculadas sobre a África [...] mostram uma África dividida e reduzida, enfocando sempre os aspectos negativos, como atraso, guerras "tribais", selva, fome, calamidades naturais, doenças endêmicas, Aids etc (MUNANGA; GOMES, 2006, p. 26).

A vinculação de artefatos visuais ${ }^{7}$ mantém uma relação estreita com as questões identitárias, uma vez que, mediadas pelos aparatos e veículos, nesse caso os livros didáticos, ela influencia, "retrata", redimensiona, ergue e edifica, ao passo que também ocasiona a ruína e desmoronamento das identidades, demonstrando que, definitivamente, as representações imagéticas não são construídas aleatoriamente, mas que estão a serviço de uma experiência visual encharcada de intencionalidades, tendo como alvo a subjetividade humana. Trata-se de uma travessia pelas experiências culturais, identitárias e quiçá pelas "consistentes" convicções, ocasionando paulatinas transformações, e muito em razão disso nos reconhecemos e nos reconstruímos no liame com o 'outro'. A natureza relacional da identidade é o cerne onde residem os nossos sentimentos, pensamentos e ações, posto que, em conformidade com Ciampa (1998, p. 34), "é o sentido da atividade social que metamorfoseia o real e cada uma das pessoas".

Por esse ângulo, a interação social parte do princípio e compreensão de que a experiência do ver e também ser visto não significa apenas um detalhe desprezível, mas um olhar que sugestiona uma perspectiva, uma intencionalidade, preconizando a visualidade sutil do bom e bonito, do ruim e feio. Isso implica, como destaca Hall (2014, p. 110), no fato de "que as identidades são construídas por meio da diferença e não fora dela. [...] apenas por

\footnotetext{
$7 \quad$ O termo artefato visuais é compreendido, neste trabalho, a partir da compreensão Sardelich (2006, p. 463), quando nos explica que: "artefatos visuais constituem veículos perfeitos para descobrirmos como percebemos a nós mesmos e compreendemos o mundo, e como percebemos e compreendemos o outro".
} 
meio da relação com o Outro". Nessa dinâmica de apreender as imagens representativas do 'outro', muitas vezes expostas como ícones padronizadores, impondo o corpo perfeito, o cabelo ideal, as medidas exatas e o comportamento aceitável; faz com que nos percebamos diferentes desse 'outro' e isso, ao passo que é "positivo", no aspecto de que 'ver e si vê', expõe nossa individualidade, nossas diferenças e põe em questão a materialidade da identidade humana, que como esclarece Ciampa (1998, p. 198 e 202) “é concreta, está sempre se concretizando [...] a concretude da identidade, que se desenvolve pelo desejo e pelo trabalho, reconhecemos, necessariamente, sua socialidade e sua historicidade".

Nessa perspectiva, recorto e ressalto uma passagem da história de vida-profissãoformação da professora Carolina, tomando-a como protagonista deste deslocamento entre a prática pedagógica, os/as alunos/as e as aprendizagens experienciais.

Em 2013 causei um burburinho na fazenda que eu trabalho, quando resolvi criar um boneco de pano negro para visitar as famílias, para que cada uma colocasse uma parte do vestuário do mesmo. Ouvi comentários horríveis por parte dos pais que muitos estudantes me relatavam, percebi que o preconceito está nos adultos, às crianças que têm atitudes preconceituosas, muitos aprenderam com os pais. Acho admirável o carinho que eles têm com o boneco, que eles chamam de Cirilo. Em 2014, Cirilo ganhou até uma irmã, que se chama Maria Joaquina, que compõe o nosso cenário lúdico para tratarmos de um assunto tão polêmico para alguns. Cirilo estará retornando em novembro de 2015, com suas peripécias para falar de consciência negra.

Existem dois importantes aspectos a serem realçados nesse marco espaço-tempo formativo da Carolina. O primeiro é concernente ao 'cenário lúdico para tratar de assuntos tão polêmicos e para falar de consciência negra' o que torna o trabalho da professora Carolina em concordância com o ensino e sua relação com a Identidade e Cultura Afro-brasileira. No entanto, apenas enfatizamos a perspectiva da diversidade que poderia ter sido contemplada pela utilização, por exemplo, de bonecas brancas, indígenas, orientais, além das pretas. Inclusive a confecção das bonecas poderia acontecer com o auxílio dos/as alunos/as e de seus familiares.

O segundo concerne ao fenômeno tão bem anotado pela professora, logo após a atividade a partir do 'boneco negro', em que ela pôde ouvir a voz em coro dos pais, reproduzido pelos/as alunos/as, explicitando a discordância em participar da incumbência de vestir o 'boneco Cirilo'. Nesse caso, a marca da diferença negra, parasitada pelo racismo, começa em casa. E se as crianças sublinham no 'boneco Cirilo' a cor negra com base na definição inferiorizante, primitivista e mitológica do/a negro/a recebida como herança de uma sociedade que tem rebocado o/a negro/a ao claustro da humilhação. 
O preconceito racial está cotidianamente dentro e fora da sala de aula por parte dos alunos, não todos mais a maioria, desde a pré-escola que crianças já recusam pegar na mão do colega, sentar juntos ou até mesmo brincar, isto porque, o colega apresenta deficiência, sofre obesidade, usam até apelidos depreciativos. Assim também agem muitos outros, de séries mais avançadas, e isso não acontece por falta de trabalho com o assunto, pois estamos sempre buscando vários textos ou encenações quanto a cultura negra. Mas, está difícil educá-los sobre os perigos do preconceito racial, porque diante do que se vê, grande parte vem do seio familiar e, por esse motivo, torna-se difícil de educá-los [...]. (Professora Clementina de Jesus)

Logo, o racismo é responsável, entre outras coisas, pela deformidade e alienação da realidade, gerando 'chagas expostas' que com o tempo vão gangrenando e necrosando a autoimagem, a autoestima e o autoconceito, favorecendo a constituição da autorrejeição, da crise identitária e aversão à pertença racial. Por exemplo, a professora Chica da Silva, ajudanos a compreender o quanto o senso inferiorizante do negro perdurou mesmo após a desintegração da sociedade escravocrata.

Na minha infância e até hoje tenho umas primas com cor de pele mais clara que eu. Elas são bem próximas a nós, mas às vezes que a encontramos pela rua, quando estão acompanhadas de alguém que não nos conhecem, fazem de conta que não estão nos vendo, mas minha mãe sempre falava e fala que deve ser por vergonha, porque somos negras não sei se é preconceito delas ou de mãe mesma.

A enunciação da professora Chica da Silva é assentada num contexto no qual se impõe um hiato cronológico de mais de cem anos do processo de abolição da escravatura no Brasil. Ainda assim, percebe-se que a desagregação do sistema escravista não pôs fim aos sentimentos de autodesvalorização e insegurança por não satisfazer o Ideal de Ego branco. Francisca e sua mãe são mulheres negras; as primas são, na equiparação, menos negras, por consequência imersas numa ideologia que lhes impeli a tomar o branco como ideal, endossando o empenho para alcançar este modelo, afinal, ser branco ou mesmo próximo é, o que se apreende, ser superior, à frente. Logo, afastar-se dos símbolos que lembrem a 'mancha e vexação negra' seria inevitável (SOUZA, 1983).

Sob outra perspectiva, Francisca não reconhece e nem discerne onde habita o preconceito: se nas "primas com cor de pele mais clara" ou em sua mãe negra. O fato é que o comportamento subterfugiado das 'primas' traz elementos reflexivos elencados por Gomes (2010, p. 146), quando afirma que: “o mulato é mais aceito do que o preto 'retinto' e que os obstáculos sociais diminuem à medida que a cor da pele clareia”. Lançamos mão do trecho dessa obra para dizer que as 'primas branqueadas' são consideradas pela sociedade, produtora de determinações econômico-político-ideológica-psíquicas, 'nem inferiores e nem 


\section{RELAÇÕES ÉTNICO-RACIAIS NA DOCÊNCIA EM CLASSES....}

superiores', isto é, para a ordem social racista de hegemonia branca tal pormenor é desprezível, associando-as, também, como 'problema negro'.

Isto posto, a estranheza denunciada pela mãe da professora Francisca subscreve, nessa relação micro e familiar, o que é desdobramento da problemática negra, ou melhor, do 'mito negro' que designa em circunstâncias profusas a marca do insólito, do diferente (SOUZA, 1983), visto que para afirmar-se ("fazem de conta que não estão nos vendo"), bem como para negar-se, reconhecendo em si um problema ("porque somos negras"), "o negro toma o branco com marco referencial" (p. 27) e nessa relação se entrevem pelo enfoque desfigurado e persistente do paradigma arcaico, no entanto neo-escravista.

Esse culto a imagem do branco como ideal de beleza, muitas vezes são artefatos que articulam informação, conhecimento, entretenimento e comunicação, publicizados com o intuito de influenciar, direcionar, alterar e macular sentidos e significados de experiências e de papéis sociais. Assim, construindo novos jeitos de ser, sentir e agir, afinal as reproduções simbólicas nos formam, construindo e configurando traços identitários que nos identificam e nos representam. Diante do exposto, o sistema educacional brasileiro determinou no decorrer do tempo a aplicação de um currículo único, sob o pretexto de oferecer uma educação "igual" para todos, ignorando os estudantes afro-brasileiros, ou indígenas, e se esses viviam em comunidades rurais ou em grandes centros urbanos. Com isso, as características singulares de cada grupo ficaram excluídas, ou ocultas, durante décadas, resultando, por exemplo, na aversão do negro a sua etnia e ancestralidade.

$\mathrm{Na}$ sua totalidade, a elite negra alimentava um sonho: assemelhar-se tanto quanto possível ao branco, [...]. Como tornar real essa semelhança a não ser através da troca de pele? Ora, para nisso chegarem, pressupunha-se a admiração da cor do outro, o amor ao branco, a aceitação da colonização e a auto-recusa. E os dois componentes dessa tentativa de libertação estão estreitamente ligados: subjacente ao amor pelo colonizador, há um complexo de sentimentos que vão da vergonha ao ódio de si mesmo. (MUNANGA, 2012, p. 37).

É a escola instituída como o 'lugar do saber', para onde convergem aqueles/as que 'não tendo saber algum' precisam consultar os conhecimentos acumulados pela história e guardados em palavras escritas nos suntuosos compêndios. Sendo assim, a escola tem o poder de instruir os "ignorantes", e durante muito tempo o exerceu as relações de poder concebendo as diferenças como "transvios", pejorativamente representadas pelas designações excludentes e homogeneizantes. Essas estratégias foram usadas no interior da escola e propagadas por professores/as que, muitas vezes sem o explícito propósito, favoreceu o aniquilamento da existência de uma identidade cultural negra, sufocando a 'raiz' 
africana, vinculando em suas aulas a experiência história dimensionada pela escravidão na ótica do colonizador, portanto os principais fatores responsáveis pelos acometimentos a base cultural africana, alterada e sucateada em tempos e lugares distintos.

No entanto, possivelmente, a escola cumprirá o seu papel de tratar os conhecimentos de todas as disciplinas de acordo com as orientações legais descritas na lei 10.639/2003, quando os órgãos de fomento à pesquisa e formação entenderem que "esse movimento depende de condições concretas relacionadas ao contexto de formação e trabalho dos docentes na educação básica" (GATTI, 2013, p. 155). Sem formação o/a professor/a continuará esboçando dificuldades de inclui nas atividades da sala de aula os conteúdos relacionados à história e à cultura africana e afro-brasileira em disciplinas, tais como: História, Artes, Língua Portuguesa e Geografia. Pois, acredita-se que oferecendo mais informações e promovendo o conhecimento sistematizado, proporcionará que os/as estudantes tenham uma visão mais crítica sobre as diferentes realidades, contribuindo para alterar as relações entre as pessoas. Podemos observas estes aspectos a partir da fala do professor Manuel

\section{Querino:}

De um tempo para cá aconteceram algumas mudanças na minha escola. Então, eu fique com alunos de educação Infantil ao terceiro ano e passei a trabalhar a identidade e a cultura afro-brasileira, mas por serem séries iniciais eu não aprofundo muito no assunto, mas não deixo de trabalhar sobre culturas, preconceito, racismo, através de pinturas, colagens, das datas comemorativas, leituras de comentários e histórias relacionadas a cultura nega.

O professor salienta a necessidade de atrelar essas atividades a projetos pedagógicos contextualizados e que valorizem a temática das relações étnico-raciais, evitando práticas pontuais e localizadas numa demarcada época do ano como maio e novembro. Desta maneira, espera-se que o referido trabalho aconteça permanentemente, atentando para problemas relacionados ao racismo levantados no cotidiano escolar. Em conclusão, é fundamental a observação, o registro e a avaliação processual da aprendizagem das crianças, ao tempo que direciona para outras intervenções mais aprofundadas em determinados aspectos do processo ensino-aprendizagem. O professor Luís Gama também relata acerca da sua experiência com a temática identidade e cultura afro-brasileira:

Comecei a ver e estudar a temática identidade e cultura afro-brasileira a partir de $2010 \mathrm{com}$ as formações do Projeto CAT (conhecer, analisar e transformar) e o Projeto Baú de Leitura ${ }^{8}$. Assim, conheci alguns livros,

8 Os projetos citados pelo professor Luís são mantidos pelo Movimento de Organização Comunitária - MOC em funcionamento desde outubro de 1967. É uma entidade civil, de direito 


\section{RELACCÕES ÉTNICO-RACIAIS NA DOCÊNCIA EM CLASSES....}

como: Menina Bonita do Laço de Fita, Cabelo de Lelê e o filme Vista a minha pele ${ }^{9}$, entre outros textos e livros. Só então, comecei a ver essa questão da identidade e valores étnicos de outra maneira. No entanto, essa temática ainda é nova para mim.

O relato do professor Luís chama atenção para um elemento fundante do desenvolvimento do trabalho pedagógico em classes multisseriadas que acontece com a organização dos discentes em diferentes níveis de aprendizagem, com a diversidade de faixas etárias e de maturidade. O que para muitos é considerado arriscado e preponderante para o fracasso escolar, particularmente consideramos como salutar, afinal a diversidade está presente na escola rural multisseriada de forma significativa exatamente por concentrar no mesmo espaço, e ao mesmo tempo, crianças de idades díspares e da Educação Infantil até os últimos anos do Ensino Fundamental. Evidente que tal contexto sobrecarrega o/a professor/a, contudo é inegável o quanto a diversidade é uma vantagem para o aprendizado em classes multisseriadas.

À vista disso, brincadeiras no espaço interno e externo da escola, rodas de leitura e conversa, oficinas de desenho, pintura, música e dança, sessão de filmes, organização de bancos de imagens, desenhos e figuras, pesquisas, confecções de murais e cartazes são bons exemplos de atividades que podem ser desenvolvidas com a estruturação de subgrupos, reunindo estudantes de diferentes idades e níveis de conhecimento. Todavia, para o/a professor/a utilizar, por exemplo, a roda na rotina da sala de aula, ele/ela precisa saber que a roda é um importante símbolo para as culturas africanas e indígenas, pois rompe com as hierarquias, permitindo um espaço para fala, a contemplação, dança e brincadeiras.

Os professores Chica e Milton nos trazem as mudanças que percebem com a inserção da discussão das relações étnico-raciais na escola:

Hoje tenho uma outra visão em relação a cultura afro-brasileira, estamos tentando mudar essa concepção, já trabalhamos bastante com projetos voltado realmente a nossa cultura. Estamos querendo mostrar aos nossos

privado, para fins filantrópicos e não econômicos, de caráter beneficente, educacional, voltado para o desenvolvimento sustentável da sociedade humana. A entidade prioriza ações no campo da incidência em políticas públicas, participação social, convivência com o Semiárido, agroecologia, relações sociais de gênero, economia solidária, educação do campo contextualizada, soberania e segurança alimentar e nutricional, desenvolvimento sustentável, direito à comunicação, entre outros.

9 O filme Vista a minha pele é do diretor Joel Zito Araújo, lançado em 2003. Trata-se de uma paródia da realidade brasileira, pois a história é invertida, isto é, os negros são a classe dominante e os brancos foram escravizados. Um significante material para a discussão sobre racismo e preconceito em sala-de-aula. 
alunos quem realmente somos e de onde viemos, eles entendem que através da nossa cultura muitos do que temos e vivenciamos vêm dos negros. Acredito que tudo o que sei não aprendi como aluna, e sim em minha prática como professora. Leciono há onze anos em uma escola multisseriada, hoje tem mais materiais disponíveis para se tratar desse assunto, mas vou lhe ser sincera: ainda é muito difícil trabalhar esse tema, pois ainda há um pouco de preconceito por parte de alunos, pais, e até mesmo por parte da sociedade, mas venho tentando da maneira que posso. (Professora Chica da Silva)

Fiquei muito grato com as descobertas [acerca da identidade e cultura afrobrasileira] depois de muitos anos trabalhando na educação, pois não sabia quase nada sobre o assunto, hoje conheço um pouco, na escola em que leciono houve até um seminário sobre a cultura africana. (Professor Milton Santos)

Apesar dos relevantes avanços e dos "materiais disponíveis para se tratar desse assunto", como destaca Chica, o/a docente precisa superar a insegurança causada pelo 'conhecimento pouco', breve e reduzido, acentuado por Milton. Assim sendo, os cursos de formação de professores/as precisam analisar as relações sociais e raciais no Brasil, promovendo o estudo teórico de conceitos, tais como: racismo, discriminação, intolerância e multiculturalismo; subsidiando as práticas pedagógicas com a utilização de materiais e textos didáticos, possibilitando a reeducação das relações étnicos-raciais. Mais que isso, é preciso oportunizar encontros entre os/as professores/as para o compartilhamento de saberes, a socialização das contrariedades, a realização de estudos e pesquisa, assim como a trocar das experiências e produção de materiais pedagógicos.

Daí a insistência das Diretrizes Curriculares Nacionais para a Educação das Relações Étnico-Raciais e para o Ensino de História e Cultura Afro-Brasileira e Africana, sobre a necessidade de investir na sólida formação dos/as professores/as, mobilizando-os/as e instigando-os/as a buscarem nas questões relacionadas à diversidade étnico-raciais, uma oportunidade para transformar a escola, por meio de estratégias pedagógicas, em um lugar que, de fato, reconhece a diversidade humana e valoriza a sua pluralidade cultural.

As diretrizes não estão exclusivamente provocando e conclamando os/as professores/as a apenas discutir a inserção da temática identidade e cultura afro-brasileira nos currículos. É algo que vai além desse propósito, pois espera alcançar a formação docente pelo viés da subjetividade, convidando-os a refletirem numa perspectiva que transcenda a tradicional prática de ensinar 'aquele que, em tese, não sabe', e assim, possam assumir uma prática a partir de contextos multiculturais, onde se encontram questões referentes às identidades étnicas. 
Para Leiro (2012, p. 23) “o processo que caracteriza a formação docente e o projeto explícito de produção cultural, como um fazer educativo intencional, resulta em grande medida de transformações ocorridas na vida [...] em diferentes tempos", suscitando, desse modo, novas preocupações educativas, como é o caso da escola e a necessidade de incorporar no seu cotidiano a valorização da cultura afro-brasileira. Dando ênfase a celebração de datas comemorativas referentes à questão racial, promovendo festas, danças e outras atividades específicas que afirmem a beleza negra, o patrimônio histórico e cultural africano e afrobrasileiro. Mas, para isso, a formação docente deve, como destaca o mencionado autor, "produzir outro percurso, de formação, de conscientização e de superação de uma dada hegemonia" (p. 30) que rechaçou os elementos basilares da identidade negra, omitindo a história, a cultura, a personalidade, a capacidade intelectual e o valor estético do negro, pois, ainda que tantas vitórias e avanços sejam realidades, o preconceito racial se alicerça na escola, através da recusa mais pungente ou do incômodo discreto em oferecer informações que elevem a autoimagem, a autoestima dos negros, promovendo o respeito, a convivência e o reconhecimento por parte de todos/as com relação à importância da população negra.

A partir do olhar de quem vive a negritude indo além da pigmentação da pele, alcançando o envolvimento emocional, ideológico, consciente do pertencimento e valor da raça e cultura negra, sabe que a escravidão, infelizmente, ainda vigora entre nós. Pois, é possível ouvir os gemidos ensurdecedores dos/as negros/as que agora não estão na senzala, mas "emergiram" para os guetos, encostas, favelas e pontes das grandes cidades, portanto regiões distantes do centro que representa o poder e o desenvolvimento; deixaram as embarcações infectas e assumiram os transportes públicos desbaratados e superlotados. Não é por acaso que o negro ocupa o lugar que tem. Portanto, a escola não pode se enclausurar na indiferença, optando por se abster de uma realidade explicitamente segregada dentro e fora dos seus muros. Os alunos/alunas continuam sofrendo os mecanismos sutis, no entanto eficazes do racismo e da discriminação. Por isso, refletir sobre a existência destas armadilhas contribui para o 'desatar' das emaranhadas posturas preconceituosas que contaminou toda a sociedade, desde as pessoas até as estruturas institucionais.

Por conseguinte, apesar dos sofrimentos e dos abalos na compreensão de 'si próprio', é preciso carregar o entendimento de pertença e de integração, portanto um dos objetivos da escola que tem condições e espaços propícios para favorecer no seu cotidiano o foco nas interações, nas relações entre as pessoas, nas atitudes e comportamentos, no entorno de gestos e imagens. Dialogando com a comunidade e estabelecendo conexões entre o cotidiano escolar e as políticas públicas, provocando as pessoas a reavaliarem os modos de pensar e 
agir. Neste sentido, o debate sobre as identidades e as culturas que moldaram as diversas formas de ser brasileiro, passa também pela escola e por seu compromisso, que não é o único, com os conhecimentos acumulados pela história universal, pois o hoje tem indeléveis e complexas ligações culturais com o passado, à vista disso, compete, segundo Rocha e Trindade (2006):

\footnotetext{
Ao professor(a) educador(a), tendo a memória e a história como perspectiva, cabe o ofício de selecionar, sistematizar, analisar e contextualizar, em parceria com seus/suas alunos(as) e quiçá, toda a comunidade escolar, o que pode ser considerado como um fato histórico, o que é relevante para um entendimento do processo histórico de reconstrução da memória que se registra nos livros e orienta uma agenda educacional. [...], por exemplo, uma outra agenda que não aponte somente na direção de uma história do Ocidente (p. 60).
}

Portanto, a superação desse estigma virá pelo prazer de ser negro, de carregar em seus traços, no crespo dos cabelos, no nariz achatado, nos lábios grossos e na cor firme, sinais genuínos de sua história. Pois, ser negro é orgulho, é seguir em frente sabendo que legiões resistiram para que existisse, enfim, uma identidade negra gestada no ventre da África, a 'Mãe negra' dos primórdios. Dessa maneira ser professor/a é se despir dos ranços, ressignificando as tensões e angústias, despertando a fome do desejo por uma relação democrática, acompanhando o processo reflexivo (pensamento: teoria e prática) de seus/suas alunos/alunas, rumo a apropriação da emancipação em detrimento da anestesia que compulsivamente cega. Por isso, a escola deve ser regida pelo princípio da promoção efetiva da autonomia estudantil, auxiliando o educando na constituição de posturas empoderadas, rompendo, definitivamente, com a desgastada figura do/a aluno/aluna bancário/a, isto é, na perspectiva daquele/aquela que tem o encargo, apenas de reproduzir o cristalizado e decidido.

\section{DERRADEIRAS E REMANESCENTES PALAVRAS}

É fato o persistente incômodo acerca do descumprimento da obrigatoriedade do ensino de História e Cultura Afro-Brasileira e Africana nas escolas da roça multisseriadas no município de Itiúba. Constrange o fato dos/as docentes das turmas multisseriadas estarem distantes das discussões concernentes as questões raciais em nosso país, onde principalmente os/as negros/as eram tratados/as como "seres inferiores" e passíveis de dominação, justificando, desse modo, o sistema escravocrata que por séculos alicerçou a economia brasileira. Inquieta o deslocamento notório desses/as professores/as sobre a preocupação a 


\section{RELACÕ̃ES ÉTNICO-RACIAIS NA DOCÊNCIA EM CLASSES....}

respeito das diversas culturas que formam o Brasil e, nesse sentido, o quanto é importante o estudo da História Africana.

À vista disso, ressaltamos a inobservância por parte da Secretaria Municipal de Educação de Itiúba à Lei no 10.639/2003 que, na época de sua publicação e vigência, não teve o seu devido reconhecimento. E quando, tardia e incipientemente, passou a se debruçar sobre suas determinações, focou em estratégias de formação a partir do modelo urbanocêntrico, desconsiderando sua realidade rural e a contingência prevalecente de professores e alunos da roça que, digam-se de passagem, têm comparado ao urbano a predominância quanto a distribuição da população afro-brasileira no município de Itiúba. Por consequência, tal incoerência, fragilizou e sobrecarregou ainda mais o trabalho pedagógico em classes multisseriadas, afinal os respectivos docentes foram obrigados a 'conciliarem' uma formação seriada num contexto não-seriado.

Portanto, de que maneira a prática do/a professor/a da roça de classes multisseriadas do município de Itiúba poderia auxiliar na superação dos mecanismos que subjugam os direitos dos povos negros, garantidos pelas políticas públicas educacionais e curriculares, se sua própria prática docente é também negligenciada? Por certo, essa condição de 'professores segunda classe' respinga no cotidiano da sala de aula. Da mesma maneira que as reproduções ultrajantes, desfavoráveis e bestiais da identidade e cultura dos povos negros, emergidas das histórias de vida, formação-profissão dos docentes da roça, também repercute no dia a dia escolar, já que as experiências vividas são formadoras, são forças que nos atingem e sobrevêm nas nossas ações e discursos.

Isto é, as falas dos/as professores/as desvelam que o que se tornou escondido e marginalizado nas relações familiares, na inicialização escolar e por todo o percurso da educação básica, culminando nos espaços intrínsecos e formativos da profissão docente, concernente ao estudo da identidade e cultura afro-brasileira, ganhando longevidade e deixando o passado para se instalar também no presente das salas de aula de professores/as

que não conseguem fazer de suas práticas pedagógicas, exímias oportunidades para o desencadeamento de processos afirmativos das identidades e da historicidade negada, tal como distorcida do povo negro.

Com efeito, a prática dos/as docentes da roça de classes multisseriadas carece de experiências reflexivas sobre uma educação antirracista, como promoveu o Ateliê (auto)biográfico, no intuito de oportunizar a compreensão dos sentidos construídos a partir da relação entre educação e questões étnico-raciais, pois a imersão nas memórias e a retomada pela narrativa indicam perspectivas formativas genuínas. 
A pesquisa-formação revelou o quanto distante estão os/as docentes da roça de classes multisseriadas dos estudos, leituras e materiais pedagógicos que auxiliem na prática educativa no tocante as identidades e cultura afro-brasileira, afinal para ensinar, exige-se o conhecimento. No entanto, percebeu-se que antes mesmo de se recorrer às informações contidas em compêndios, livros e em pesquisa acerca das questões já mencionadas, é preciso refletir sobre o lugar do negro nas histórias de vida desses professores para que, dessa maneira, possam agir diante do segregamento presento no 'outro'. Logo, a hipotética 'mediocridade' utilizada como explicação por não haver uma maior aplicação da lei $\mathrm{n}^{\circ}$ 10.639/2003 pelos/as professores/as, definitivamente não se sustenta.

Por fim, refletimos, debatemos e dialogamos em torno dos ideários de negação e submissão para alcançar a certeza de que ser negro, ser negra, exige um ânimo descomedido. Entretanto, uma vez que há a aceitação de sua história e que já não há dor em reconhecer-se membro deste corpo negro, vem o esforço para combater as barreiras discriminatórias e auxiliar no desenvolvimento de um novo ser humano, capaz de se elevar à altura de seu destino vencendo os ardis de uma sociedade em evolução. É neste sentido que pretendemos que este trabalho possa ser um aporte de estudos e formação acerca das questões étnicosraciais e, consequentemente, aproximar a Lei no 10.639/2003 da prática pedagógica dos/as docentes de classes multisseriadas, alterando esta realidade educacional.

\section{REFERÊNCIAS}

ASETTT. ASSOCIAÇÃO ECUMÊNICA DE TEÓLOGOS DO TERCEIRO MUNDO. Identidade negra e religião. Rio de Janeiro: CEDI, 1986.

BRASIL, Ministério da Educação e do Desporto. Parâmetros Curriculares Nacionais pluralidade cultural e orientações sexuais. Temas transversais, Brasília, v. 10, p. 1-126, 1997.

BRASIL, Ministério da Educação/Secretaria de Educação Continuada, Alfabetização e Diversidade/Secretaria Especial de Política de Promoção da Igualdade Racial. Diretrizes Curriculares Nacionais para a Educação das Relações Étnico-Raciais epara o Ensino de História e Cultura Afro-Brasileira e Africana. Brasília, DF: MEC/SECAD/SEPPIR, 2005.

BRASIL. Constituição (1988). Constituição da República Federativa do Brasil. Brasília, DF: Senado, 1988.

BRASIL. Lei 10.639/2003, de 9 de janeiro de 2003. Altera a Lei nº 9. 394, de 20 de dezembro de 1996. Diário Oficial da União, Poder Executivo, Brasília.

BRASIL. Lei 11.645/2008 de 10 de março de 2008. Diário Oficial da União, Poder Executivo, Brasília. 
CANCLINI, N. G. Culturas híbridas: estratégias para entrar e sair da modernidade. 4. ed. São Paulo: EDUSP, 2013.

CAVALLEIRO, E. Introdução. In: BRASIL, Ministério da Educação/Secretaria da Educação Continuada, Alfabetização e Diversidade. Orientação e ações para a educação das relações étnico-raciais. Brasília, DF: MEC/SECAD, 2006. p. 13-26.

CAVALLEIRO, E. Introdução. In: BRASIL. Ministério da Educação, Secretaria de Educação Continuada, Alfabetização e Diversidade. Educação anti-racista: caminhos abertos pela Lei Federal no 10.639/03. Brasília, DF: MEC/SECAD, 2005. p. 11-18.

CIAMPA, A. da C. A estória do Severino e a história da Severina: um ensaio de psicologia social. São Paulo: Brasiliense, 1998.

COLASANTI, M. Doze Reis e a Moça no Labirinto do Vento. Global Editora, Rio de Janeiro, 2000.

COSTA, J. F. Da cor ao corpo: a violência do racismo. In: SOUZA, N. S. Tornar-se negro: as vicissitudes da identidade do negro brasileiro em ascensão social. Rio de Janeiro: Graal, 1983. p. 1-16.

D'ADESKY, J. Pluralismo étnico e multiculturalismo: racismos e anti-racismos no Brasil. Rio de Janeiro: Pallas, 2009.

FANON, F. Pele negra, máscaras brancas. Salvador: EDUFBA, 2008.

FERNANDES, F. O negro no mundo dos brancos. São Paulo: Difusão Européia do Livro, 1972.

GATTI, B. A. Valorização da docência e avaliação do trabalho docente. In: GATTI, B. A. (Org.). O trabalho docente: avaliação, valorização, controvérsias. Campinas, SP: Autores Associados; São Paulo: Fundação Carlos Chagas, 2013. p. 153-176.

GENTILI, P. et al. Educação e população afrodescendente no Brasil: avanços, desafios e perspectivas. Madrid: Fundación Carolina - CeALCI, 2011.

GOMES, N. L. Uma dupla inseparável: cabelo e cor da pele. In: BARBOSA, L. M. de A. et al. (Orgs.). De preto a afro-descendente: trajetórias de pesquisa sobre relações étnico-raciais no Brasil. São Carlos: EdUFSCar, 2010. p. 137-150.

HALL, S. Quem precisa da Identidade? In: SILVA, T. T. (Org.). Identidade e diferença: a perspectiva dos estudos culturais. Petrópolis, RJ: Vozes, 2014. p. 103-133.

IBGE. INSTITUTO BRASILEIRO DE GEOGRAFIA E ESTATÍSTICA. Censo Demográfico 2010. Disponível em: <http://censo2010.ibge.gov.br/>. Acesso em: 02 mai. 2015.

LEIRO, A. C. R. Formação docente e educação básica: currículo e arranjos de pesquisas. In: LEIRO, A. C. R.; SOUZA, E. C. de (Orgs.). Educação básica e trabalho docente: políticas e práticas de formação. Salvador: EDUFBA, 2012. p. 23-37.

MACEDO, R. S. Currículo, diversidade e eqüidade: luzes para uma educação intercrítica. Salvador: EDUFBA, 2007. 
MUNANGA, K. Negritude: usos e sentidos. Belo Horizonte: Autêntica Editora, 2012.

MUNANGA, K.; GOMES, N. L. Para entender o negro no Brasil de hoje: história, realidades, problemas e caminhos. São Paulo: Global: Ação Educativa Assessoria, Pesquisa e Informação, 2006.

NETA, L. B. Formação do professor: um olhar psicopedagógico. In: LEIRO, A. C. R.; SOUZA, E. C. de. (Orgs.). Educação básica e trabalbo docente: políticas e práticas de formação. Salvador: EDUFBA, 2012. p. 295-309.

RIOS, J. A. V. P. Ser e não ser da roça, eis a questão! Identidades e discursos na escola. Salvador: EDUFBA, 2011.

ROCHA, R. M. de C.; TRINDADE, A. L. da. Ensino fundamental. In: BRASIL. Ministério da Educação, Secretaria da Educação Continuada, Alfabetização e Diversidade. Orientação e ações para a educação das relações étnico-raciais. Brasília, DF: MEC/SECAD, 2006. p. 53-75.

SARDELICH, M. E. Leitura de imagens, cultura visual e prática educativa. Cadernos de Pesquisa, v. 36, n. 128, p. 451-472, mai./ago. 2006.

SILVA. M. do S. Diretrizes operacionais para escolas do campo: rompendo o silêncio das políticas educacionais. In: BAPTISTA, F. M. C.; BAPTISTA, N. de Q. (Orgs.). Educação rural: sustentabilidade do campo. Feira de Santana, BA: MOC; UEFS; (Pernambuco): SERTA, 2003. p. 29-51.

SOUZA, N. S. Tornar-se negro: as vicissitudes da identidade do negro brasileiro em ascensão social. Rio de Janeiro: Edições Graal, 1983. 